\title{
Article
}

\section{Betwixt fiction and documentary}

Shōhei, Imamura

Available at http://clok.uclan.ac.uk/21661/

Shōhei, Imamura (2017) Betwixt fiction and documentary. Asian Cinema, 28 (1). pp. 101-105. ISSN 1059-440X

It is advisable to refer to the publisher's version if you intend to cite from the work. http://dx.doi.org/10.1386/ac.28.1.101_1

For more information about UCLan's research in this area go to

http://www.uclan.ac.uk/researchgroups/ and search for < name of research Group>.

For information about Research generally at UCLan please go to http://www.uclan.ac.uk/research/

All outputs in CLoK are protected by Intellectual Property Rights law, including Copyright law. Copyright, IPR and Moral Rights for the works on this site are retained by the individual authors and/or other copyright owners. Terms and conditions for use of this material are defined in the policies page.

\section{CLoK}

Central Lancashire online Knowledge www.clok.uclan.ac.uk

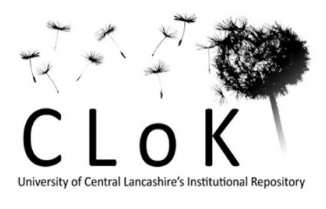




\section{Betwixt Fiction and Documentary}

Imamura Shōhei, "Fikushon to Dokyumentari no Awai de," in Toru: Kannu kara

Yamiichi e (Tokyo: Kōsakusha, 2001), pp. 234-8.

Bill Mihalopoulos 


\section{Betwixt Fiction and Documentary}

Imamura Shōhei, "Fikushon to Dokyumentari no Awai de," in Toru: Kannu kara Yamiichi e (Tokyo: Kōsakusha, 2001), pp. 234-8.

Translation note:

In most instances I have chosen not to translate Imamura's use of the word Kami. The primary reason is because of the social, cultural and historical ambiguity embedded in the term. At times Imamura associates Kami with the idea of the Japanese Emperor as Divine Being. At other times Kami seems to refer to the presence of a divine omniscient entity. However, more often than not, Imamura's use of Kami seems to connote the unseen psychological forces that give meaning, context and impetus to individual action.

I believe the film drama Kamigami no Fukaki Yokubō/The Profound Desire of the Gods (1968) was my magnum opus in the first-half of my life as a director,

It was a period when Imamura Production was becoming independent of Nikkatsu. Imamura Production had already made plans to make Nigen Jōhatsu/A Man Vanishes (1967). I was also writing the scenario for Erogotoshitachi/The Pornographers (1966) ${ }^{1}$ and the fifth draft of Kamigami/The Profound Desire of the Gods. And to boot, I was writing the docu-drama The Coward/Yowamushi Ari while clamouring around preparing to send a film crew to Morocco for the shoot. 
It was such a busy period of my life. Even now when I try to remember, it is impossible to order my scattered recollections. At that time, the notion of "Kami" was always occupying my thoughts, however. It was not just in this particular period in my life; from the end of the [Pacific] war the notion of Kami was never far from my mind. What was the Kami of the Japanese people? I foraged for an answer in books of metaphysics, but I failed to discover anything. Yet, in the desire of the body I detected the scent of something Kami-like.

I was eighteen when the war ended. The war years were nothing but enforced formality and stress. During this time, we put our hopes and desires aside. After the war, I was a player in the black market, living alongside other black marketeers amidst the burnt out ruins of the city. My involvement in the black market took me by surprise. From the earliest years, I always held a strong reverence towards women. The women in my family - my grandmother, mother, and older sister - were the ones with real ability. It was in the streets of the black market however, that I saw women in open conflict over their true intentions for the first time. It was acceptable for women to jump into the fray of the streets and use their bodies as a means to get their hands on food. Eventually it dawned on me. The truth of the matter was that this was the only option available to them. In the ruins of defeat, it felt like there was no opening for the Divine (Kami) to intervene. ${ }^{2}$ The Emperor stated: "I am not Divine. I am only human.” Moreover, the nuclear holocaust would not have been possible if there was a Divine Being as espoused by the West. Even though Hitler was a crazy lunatic, America did not drop the nuclear bomb on Berlin, nor 
did it rain nuclear destruction on Milan in the face of stubborn resistance from the Italians.

Reading Ango Sakaguchi's Darakuron/On Decadence (1946) in my small two tatami black market stall, I gave thought to how the only way to directly confront Kami was inductively, around the clash of ideas concerning women and rice, both of which sustain life in Japan.

Now, the Okinawa weather for Kamigami/The Profound Desire of the Gods was exceedingly bad. I banked that the months from March to September would comply with bright sunny days. The opposite happened. We had incessant heavy overcast days. A typhoon reached Okinawa but its progress was blocked by a high pressure cell over the main islands of Japan. At one time the typhoon backtracked to the Philippines, only to reappear once more over Okinawa.

We ended up spending a year in the rain, using up the entire budget, and having to extend shooting into a second year. We still had eighty percent of the film to shoot. Still, for all of that, the weather was vastly better in the second year. After shooting finished for the day, I was able to have long talks with the local inhabitants over drinks. I still do not understand much about the ways of Kami, but my "Kami" is very functional. What I know is that my "Kami" is very different from a monotheistic God: it is something akin to a mix between the Kami found in nature and the Kami of human ancestors (Sosen Kami). 
Conversations with the local inhabitants were fascinating - much more interesting than the exchanges I had with cast and crew. For example, they talked about how the spirit (tamashii) often leaves the body and the grave consequences of coming into contact with one. ${ }^{3}$ Or how all contests involved the potent backing of women; it was said victory was ensured if women placed a curse on rivals. One would imagine that those involved would be unmotivated to compete. Yet, in order to win, they would slyly apply themselves. Be this as it may, the assistance of women was an undeniable and essential precondition for success as far as the local inhabitants were concerned.

I wanted the actors to hear these conversations too. However, they paid little heed. Actors are cut from an entirely different cloth. They are people who make a living based on artifice. From the time I decided to search for the trace of Kami in each individual phenomenon, I could no longer detect the workings of Kami in actors. I think it was because I was convinced that the only way I could see evidence of Kami was in the actualities of life. The inhabitants of the Yaeyama Islands at the remote edge of Okinawa seemed to possess a direct gateway to their Kami. The Kami of Yaeyama were foreign to me, yet I wanted to use the idiosyncratic and distinct local practices as footing to confront my own Kami. When I would turn from a conversation and ask the actors "Guys, what you think of this?" they were always engaged elsewhere.

Actors are bores. Since the popularity of TV, actors have become particularly tiresome. I believe that I switched [from making commercial films] to documentaries when I 
resolved to show the effects of Kami by making actual, bona fide people's lives the subject of my work rather than the imitation of actors. My experience in Okinawa left me dissatisfied. In a sense, making my way to the backwoods of Borneo via Taiwan, the Philippines, and the Malaya Peninsular was also an extension of my quest to locate $\mathrm{Kami}^{4}{ }^{4}$ On the surface I was searching to find unreturned soldiers, but in reality I was seeking Kami. I started to think about the meaning of the Emperor around the questions: "Under the name of the Emperor, I fought in foreign lands and when the war ended I was abandoned. Who discarded me even while my life and body was pressed to serve and die for the Emperor? From the outset, who drove me to war?" Japanese businessmen, the troops of the new Emperor, started to appear in Southeast Asia in due time after the war. At first glance, they looked like Americans. Irrespective of what or who was investigated, the television documentaries failed to fully answer these questions. Amongst the unreturned soldiers, there was one who had converted to Islam. In broken Japanese he vented his ire. However, it was a view adopted from his new religion and lacked conviction.

I made Ningen Jōhatsu/A Man Vanishes a year before Kamigami/The Profound Desire of the Gods. The two films blur into one however, as I had already started on my individual quest to unearth Kami over half a year earlier.

Actors cannot be relied upon; their motives are not the same. As previously stated, they make their living by pretending to be someone else. Yet, to a man the non-repatriated 
soldiers too became affected when they faced the camera. They assumed the airs of an actor, despite being real hams because of their clumsy, broken Japanese.

"Mouse" (Yoshie Hayakawa), the protagonist of Ningen Jōhatsu/A Man Vanishes, became an "actress" less than a month into shooting; "Rabbit" (Sayo Hayakawa), "Mouse's" older sister, less so. ${ }^{5}$ The story line consists of "Mouse" tracking down her fiancée Ōshima Tadashi, an ordinary white collar worker. The production staff suspected that Ōshima disliked "Mouse," who was forced upon him by the company owner, and that he was predisposed to her older sister "Rabbit". No script was given to "Mouse" as she followed clues to her fiancée's whereabouts, but we had the actor Tsuyuguchi Shigeru assist her. After discussions with others and despite my embarrassment, I appeared in front of the camera to counteract "Mouse's" lack of openness. At one point the two sisters confront each other in a fake room (in reality, a set in a film studio). Because that shrill and disagreeable "Mouse" had become an actress, the force of her character was missing, and she lost her squabble with "Rabbit." I collapsed the set in the end with the intention of revealing the betwixt of drama and documentary. The results were ambiguous however, because of the failure to get to the heart of the matter. ${ }^{6} \mathrm{I}$ believe that this was down to "Mouse's" lack of urgency to search for the truth. Because "Mouse" had become an "actress" she was no match for "Rabbit." No matter how many pieces of circumstantial evidence were thrust under "Rabbits" nose, she adamantly denied knowing anything. Unlike "Mouse," "Rabbit" was convinced that we were shooting a documentary. The difference in intensity was unmistakable. 
Initially there was the expectation that a hysterical "Mouse" would accuse "Rabbit," who in turn would obstinately deny any knowledge, and in due course "Mouse" would start throwing the crockery at hand and the conflict would evolve into open carnage. I think the dismantling of the set would have worked effectively if things went that far.

After we dismantled the set, we received information that a young man had recently met Ōshima when he appeared in a small hole-in-the-wall bar in Hakata (Fukuoka) wearing a yellow helmet.

Excitedly, we put the staff on stand-by ready to shoot while we waited for the young man. All the cameras were rolling the moment he entered the studio. This time, "Mouse" and "Rabbit" formed a mutual alliance and hauled the young man over the coals. Bewildered by the ferocity of their attack - "Rabbit" thinking it was documentary reportage; "Mouse" being an actress - the young man was left speechless. He appeared completely lost, unable to counter "Rabbit's" accusation that he was a liar. Loathing to finish with this badly improvised performance, the film meanders to some sort of ending with the last scene of people assembling on the set.

I thought some outcome was possible around the question of "Kami" and documentary or actress and "Kami." My thinking only became confused however, and in the end I was again left betwixt and between. 
My first commercial film after a nine-year break was Fukushū Suru wa Ware ni Aru/Vengeance is Mine (1979) based on a true story. I thought the script would be difficult to shoot. I abhor actors. But after working successfully with them, I could see they have their uses. I could not help thinking when I saw the actors immerse themselves in their individual roles that in the betwixt of the individual actor and their performance it was possible to discover Kami.

There are all types of actors. We differentiate actors from actresses straightforwardly according to sex. However, the substance of the two is very different. Male actors are accepted as they are. When it comes to actresses however, we feel compelled to call them either a temptress or hellcat. This is because they follow their instinct rather than logic.

I think this [differentiation of male and female actors] is similar to the assertions made in past controversies such as "Co-eds and National Decay" that argued women were an irrational subspecies that had infiltrated the house of Reason built by men. ${ }^{7}$ However, it is impossible to have a world without women. I do not think it is such a bad thing to take up a life-of-study investigating the existence of Kami via associations with women.

In the past, the actor Tonoyama Taiji (1915-1989) called for a shikishi ${ }^{8}$ in a Toruko-Buro ${ }^{9}$ and wrote: "Pursue the Truth." Everyone laughs at this. However, the fact is I appreciated Tonoyama's unquenchable thirst to investigate the world in his old age. 
I mentioned previously that "Mouse" became an actress. As an actress, she was visceral.

She is not comparable to a male actor. I still regret that in my pursuit of the true character of "Mouse" I was unable to penetrate the substance of her primal nature.

\section{Acknowledgement}

I am indebted to Jonathan Bunt for his assistance in refining the translation. 


\section{Endnotes}

${ }^{1}$ The full title is Erogotoshitachi yori- Jinruigaku Nyūmon/The Pornographers:

Introduction to Anthropology.

${ }^{2}$ Imamura seems to be asking: How does one live in a world in which all principles have been shattered to bits?

${ }^{3}$ Imamura seems to be talking about the Okinawan belief of mabui - life essence or soul - and how the mabui of the dead may cling to the living. See the Kiyama Shōhei and Kawabata Yasunari literary prize winning short story by Medoruma Shun (Medoruma 2011, pp 112-34.). My gratitude to Christopher T. Nelson for drawing my attention to Medoruma Shun's short story.

${ }^{4}$ In the first half of the 1970s Imamura made three documentaries for Tokyo Channel 12 that focused on former Japanese soldiers of the Japanese Imperial Army who made a life for themselves in Southeast Asia rather than return to their homeland. The documentaries were: Mikikanhei wo Otte - Marei-hen /In Search of the Unreturned Soldiers in Malaysia (1971), Mikikanhei wo Otte-Tai-hen /In Search of the Unreturned Soldiers in Thailand (1971); and Muhomatsu Kyoko ni Kaeru/Outlaw Matsu Returns (1973).

5 "Mouse" and "Rabbit" are the diminutive nicknames Imamura and his crew gave the two women during the course of shooting the film.

${ }^{6}$ Imamura and his staff believed that Sayo Hayakawa and Ōshima were lovers and that he had "disappeared" to escape Yoshie. 
${ }^{7}$ The debate centred on the issue of integrating female students in the Japanese university, previously a male-bastion. This issue erupted into a topic of public interest in 1962 when Waseda University professor Teruoka Yasutaka outlined his view of women attending university in his article "Coeds and National Decay" (Joshigakusei bōkokuron) in the March issue of Fujin kōron/Women's review. Teruoaka opposed young women studying in the humanities because their alleged superficiality undermined the cultural transmission of knowledge and values to the next generation of Japanese men.

Teruoaka's solution was a quota limiting the number of female admissions (Hirakawa 2002, p, 106; Bullock 2014, pp. 9-10, 12-15).

${ }^{8}$ Usually refers to rice paper (usually white) laminated to a hard board backing and used for calligraphy or ink painting.

${ }^{9}$ Toruko-Buro (literally Turkish Baths) was the term used for places now known in Japan as "Soapland" - and refers to "baths" where men can go and pay for sex. The name changed from Toruko-Buro to Soapland in 1984 due to the objections of Turkish citizens residing in Japan, who claimed it was a personal and national affront to make Turkey synonymous with the sex industry.

\section{References}

Bullock, J. C. (2014), "“Female Students Ruining the Nation:” The Debate over Coeducation in Japan', U.S.-Japan Women's Journal, 46, pp. 3-23.

Erogotoshitachi yori- Jinruigaku Nyūmon/The Pornographers: Introduction to Anthropology (1966) 
Hirakawa H. (2002), 'Maiden Martyr for 'New Japan': The 1960 Ampo and the Rhetoric of the Other Michiko', U.S.-Japan Women's Journal, 23, pp. 92-109.

Kamigami no Fukaki Yokubō/The Profound Desire of the Gods (1968)

Medoruma S. (2011), 'Mabuigumi', in F. Stewart and K. Yamazato (eds.), Living Spirit: Literature and Resurgence in Okinawa (MĀNOA) [trans. K. Ikeda], Honolulu, University of Hawai'i Press, pp. 112-134.

Mikikanhei wo Otte - Marei-hen /In Search of the Unreturned Soldiers in Malaysia (1971)

Mikikanhei wo Otte-Tai-hen /In Search of the Unreturned Soldiers in Thailand (1971)

Muhomatsu Kyoko ni Kaeru/Outlaw Matsu Returns (1973)

Nigen Jōhatsu/A Man Vanishes (1967) 